\title{
Infrared absorption spectra of bis(monofluorocarbonyl)-and bis(trifluoromethyl)—peroxides
}

\author{
A. J. Arvía and P. J. Aymonino \\ Instituto Superior de Investigaciones, Facultad de Química y Farmacia, \\ Universidad Nacional de La Plata, La Plata, República Argentina
}

(Received 22 November 1961)

\begin{abstract}
Infrared absorption spectra of gaseous $(\mathrm{FCO})_{2} \mathrm{O}_{2}$ and $\left(\mathrm{F}_{3} \mathrm{C}\right)_{2} \mathrm{O}_{2}$ have been obtained in the $\mathrm{NaCl}$ and $\mathrm{KBr}$ regions. By comparison with the spectra of $\mathrm{F}_{2} \mathrm{CO}$ and $\mathrm{F}_{3} \mathrm{COF}$, most of the bands related to fundamental vibration modes of the molecules of both peroxides have been identified. Results agree with the structure previously postulated for both substances.
\end{abstract}

\section{INTRODUCTION}

BIS(MONOFLUOROCARBONYL)PEROXIDE (BMFCP) was recently discovered as the principal product of the thermal reaction between fluorine, carbon monoxide and a large excess of oxygen carried out in the range $0-50^{\circ} \mathrm{C}$ [1-3].

Years ago, bis(trifluoromethyl)peroxide (BTFMP) was isolated by Swarts [4] from the electrolysis by-products of trifluoroacetic acid. Later PORTER and CADY [5] prepared BTFMP by allowing fluorine and carbon monoxide to react both diluted with nitrogen in the presence of fluorinated silver. They obtained the infrared absorption spectrum of this substance in the region between 1 and $10 \mu$ but did not discuss the details of the spectrum. In this paper spectra of both peroxides in the region $2 \cdot 5-25 \mu$ have been analysed. This analysis is based on the similarities between the spectra and also on the comparison with spectra of other molecules which contain the same atomic groups. In this way it was possible to identify a large number of bands due to fundamental vibrations and to relate them with the structures previously postulated for those molecules.

\section{EXPERIMENTAL}

BMFCP was obtained by the reaction between fluorine, carbon monoxide and oxygen at room temperature [3]. It was purified by distillation at low temperature and reduced pressure. BTFMP was prepared according to PoRTER and CADY [5] and also purified by distillation in the usual way. Infrared absorption spectra were recorded with a Perkin-Elmer double-beam Spectrometer Model 221, provided with the $\mathrm{NaCl}$ prism-grating or the $\mathrm{KBr}$-prism interchange. Spectra were obtained of the

[1] A. J. Arvif, P. J. Aymonino, C. H. Waldow and H. J. Schumacher, Angew. Chem. 72, 169 (1960).

[2] J. M. Heras, A. J. Arvía, P. J. Aymonino and H. J. Schumacher, Z. physik. Chem. (Franlefurt) 28, 250 (1061).

[3] A. J. Arvía, P. J. Aymonino and H. J. Schumacher, $Z$. anorg. u. allgem. Chem. In press.

[4] F. Swarts, Bull. soc. chim. Belge 42, 102 (1933).

[5] R. S. Porter and G. H. CAdy, J. Am. Chem. Soc. 79, 5625 (1957). 
gaseous samples at pressures between a few tenths of a $\mathrm{mm}$ of $\mathrm{Hg}$ up to ca. $600 \mathrm{~mm}$ of $\mathrm{Hg}$ in $10-\mathrm{cm}$ path length cells, with $\mathrm{NaCl}$ or $\mathrm{KBr}$ windows attached with Halocarbon grease. Coll and vaouum line taps were lubricated with the same grease. Pressures in the cell were measured with a Bodenstein manometer made of quartz. Another similar cell containing dry air at atmospheric pressure freed from carbon dioxide was used as a reference. As both cells had not exactly the same length, the contours of the bands were distorted in the regions where (atmospheric) carbon dioxide and water also absorb. By running blank spectra it was possible to allow for this interference. The dotted lines in Fig. 1-4, which show the spectra of both peroxides, indicate the regions affected by the spurious absorption. 'Tables 1 and 2 include the frequencies of the bands, their relative intensities and interpretation.

\section{Discession}

In the molecules studied in this work, as in the case of hydrogen peroxide [6] and bis(pentafluorosulphur)peroxide [7], the chain formed by peroxidic oxygen and neighbour atoms $(-\mathrm{C}-\mathrm{O}-\mathrm{O}-\mathrm{C}-$ ) is probably not lying in a plane. Therefore, BMFCP and BTFMP molecules could be assigned to the point groups $C_{1}$ or, less probably, to $C_{2}$. Consequently their infrared spectra should have all the bands related to the $3 N-6$ fundamental vibrations. Most of the bands we have obtained do not show any structure due, undoubtedly, to the complexity of both molecules.

\section{(a) The BMFCP spectrum}

Having eight atoms, the BMFCP molecule should have eighteen IR-active fundamental bands. As it may be seen from Table 1, many of these, and their overtones and combinations, have been identified.

In order to visualize its normal modes of vibration, the BMFCP molecule could be divided into two $\mathrm{O}=\mathrm{C}_{\mathrm{O}}^{\mathrm{C}}$ groups by a plane bisecting the $\mathrm{O}-\mathrm{O}$ bond. Probably, those groups are planar as in the carbonyl halides. We could expect, therefore, bands due to the $\mathrm{C}=\mathrm{O}, \mathrm{C}-\mathrm{F}$ and $\mathrm{C}-\mathrm{O}$ stretching vibrations and to the out-of-plane and the angular deformations (symmetric and asymmetric with respect to the $\mathrm{C}-\mathrm{O}$ bond). The remaining bands should involve the following motions: the torsion of the

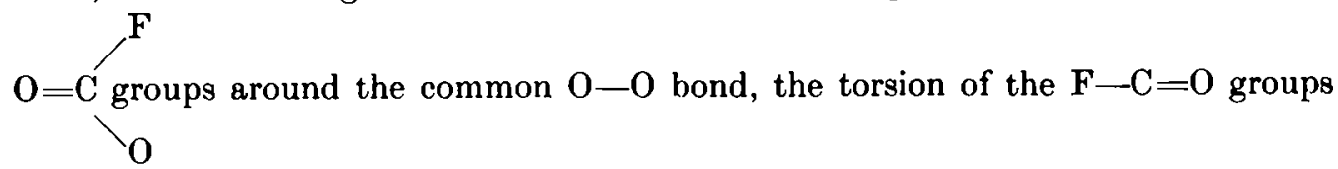
around the $\mathrm{C}-\mathrm{O}$ bonds, the deformation of the $\mathrm{O}=\mathrm{C}-\mathrm{O}$ angles and the stretching of the $\mathrm{O}-\mathrm{O}$ bond.

The comparison between the $\mathrm{O}=\mathrm{C}_{\mathrm{O}}^{\mathrm{F}}$ groups and the carbonyl difluoride molecule

[6] P. A. Gigctère and U. BAin, J. Phys. Chem. 56, 340 (1952).

[7] R. B. Hakvfy and S. H. Baler, J. Am. Chem. Suc. 76, 859 (19.54). 


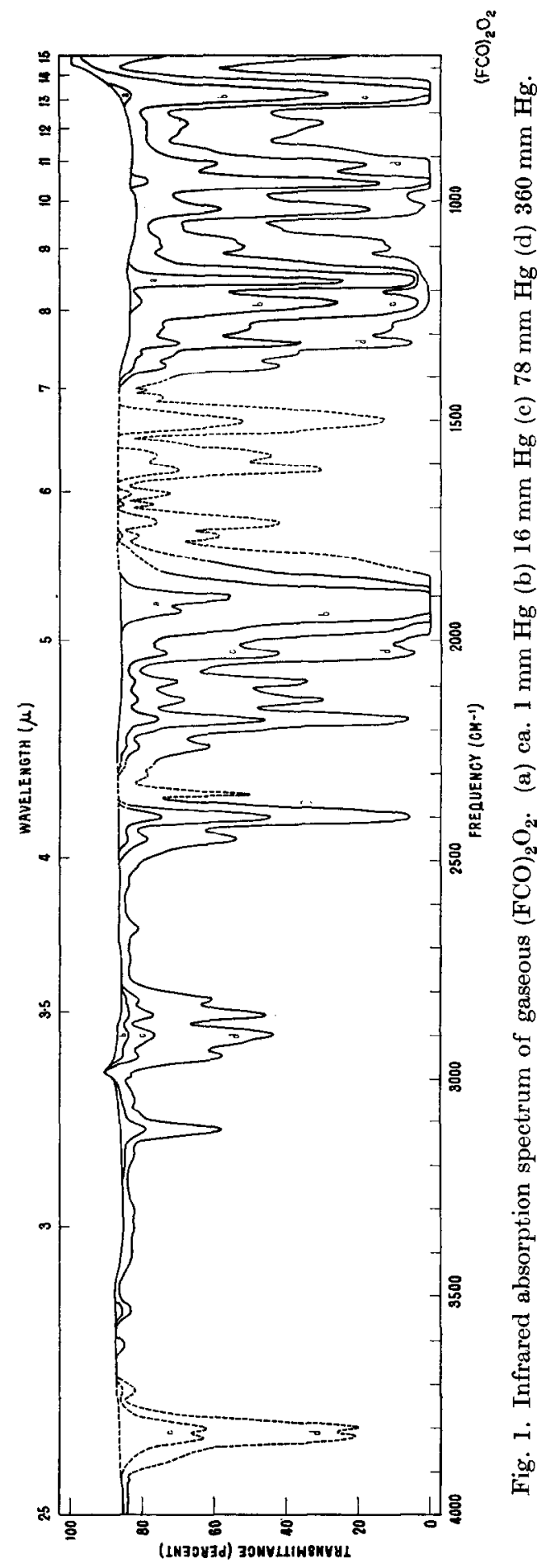


has proved to be particularly useful. Oxygen and fluorine are immediate neighbours in the periodic system differing little in electronegativity and atomic weight, therefore the replacement of one element by the other in a molecule should not change essentially the position of the bands originated by their stretching and deformation vibrations (compare Ref. [8]). For instance, the $\mathrm{C}-\mathrm{X}(\mathrm{X}=\mathrm{F}, \mathrm{OH})$ stretching bands in methyl fluoride and methyl alcohol are very elose (1048 and $1034 \mathrm{~cm}^{-1}$, respectively).

On the other hand, the $\mathrm{C}-\mathrm{F}$ asymmetric and symmetric stretching bands in

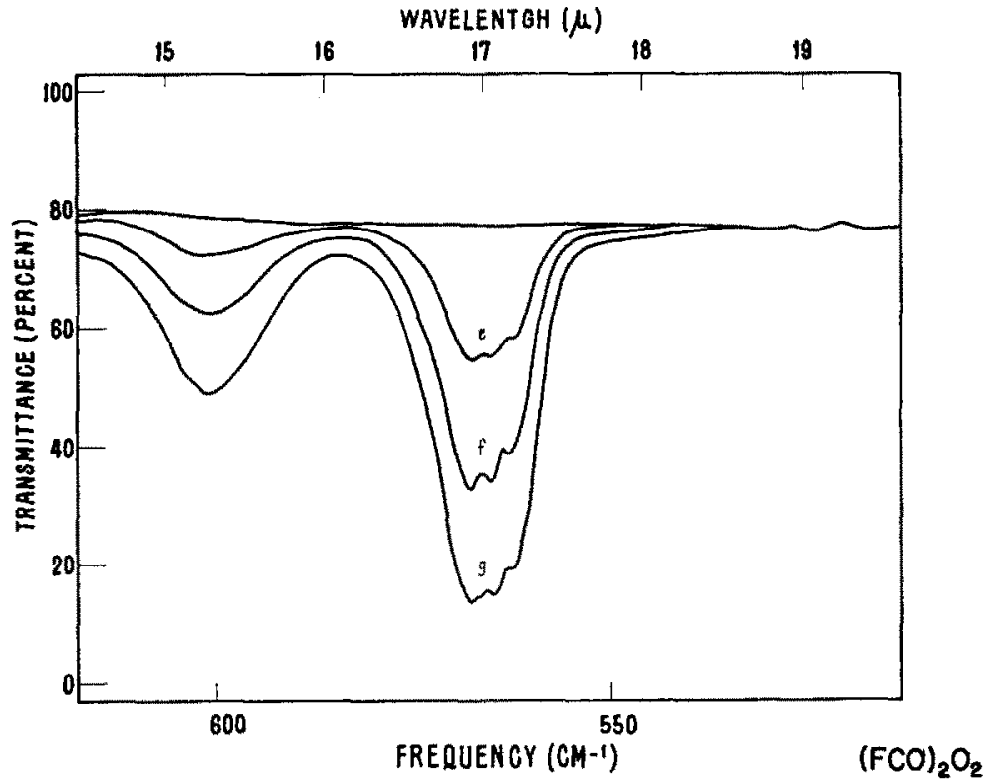

Fig. 2. Infrared absorption spectrum of gaseous $(\mathrm{FCO})_{2} \mathrm{O}_{2} \cdot \quad$ (e) $10 \mathrm{~mm} \mathrm{Hg}$ (f) $26 \mathrm{~mm} \mathrm{Hg}(\mathrm{g}) 48 \mathrm{~mm} \mathrm{Hg}$.

$\mathrm{F}_{2} \mathrm{CO}$ [9] are located at 1249 and $965 \mathrm{~cm}^{-1}$, precisely in the regions where alkyl carbonates also have their stretching bands [8] (between 1205 and 1280, and at ca. $950 \mathrm{~cm}^{-1}$, respectively).

Those facts suggest that the $\mathrm{C}-\mathrm{F}$ and $\mathrm{C}-\mathrm{O}$ stretching bands, assuciated with the

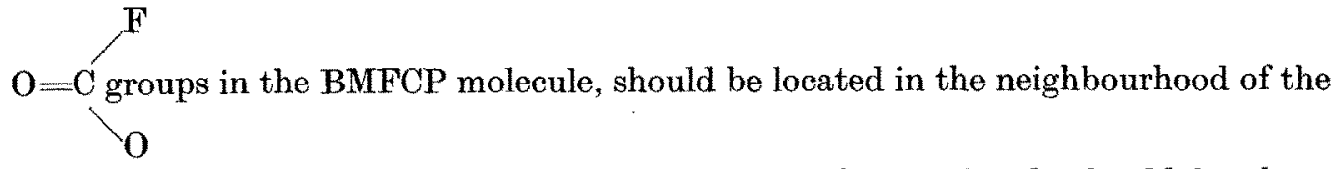

above mentioned frequencies. The most intense of those bands should be those related to the $\mathrm{C}-\mathrm{F}$ stretching vibration because it always gives rise to bands of exceptionally high intensity. Furthermore, bands due to the $\mathrm{C}=\mathrm{O}$ stretching vibration and to the $\mathrm{O}=\mathrm{C}$ out of-plane ("skeletal") deformation should be expected

[8] R. A. Nyquist and W. J. Potrs, Spectrochim. Acta 17, 679 (1961).

[9] A. H. Nifisfin, T. G. Burke, P.J.H. Woutz and E. A.Jones, J. Chem. Phys. 20,596 (1952). 


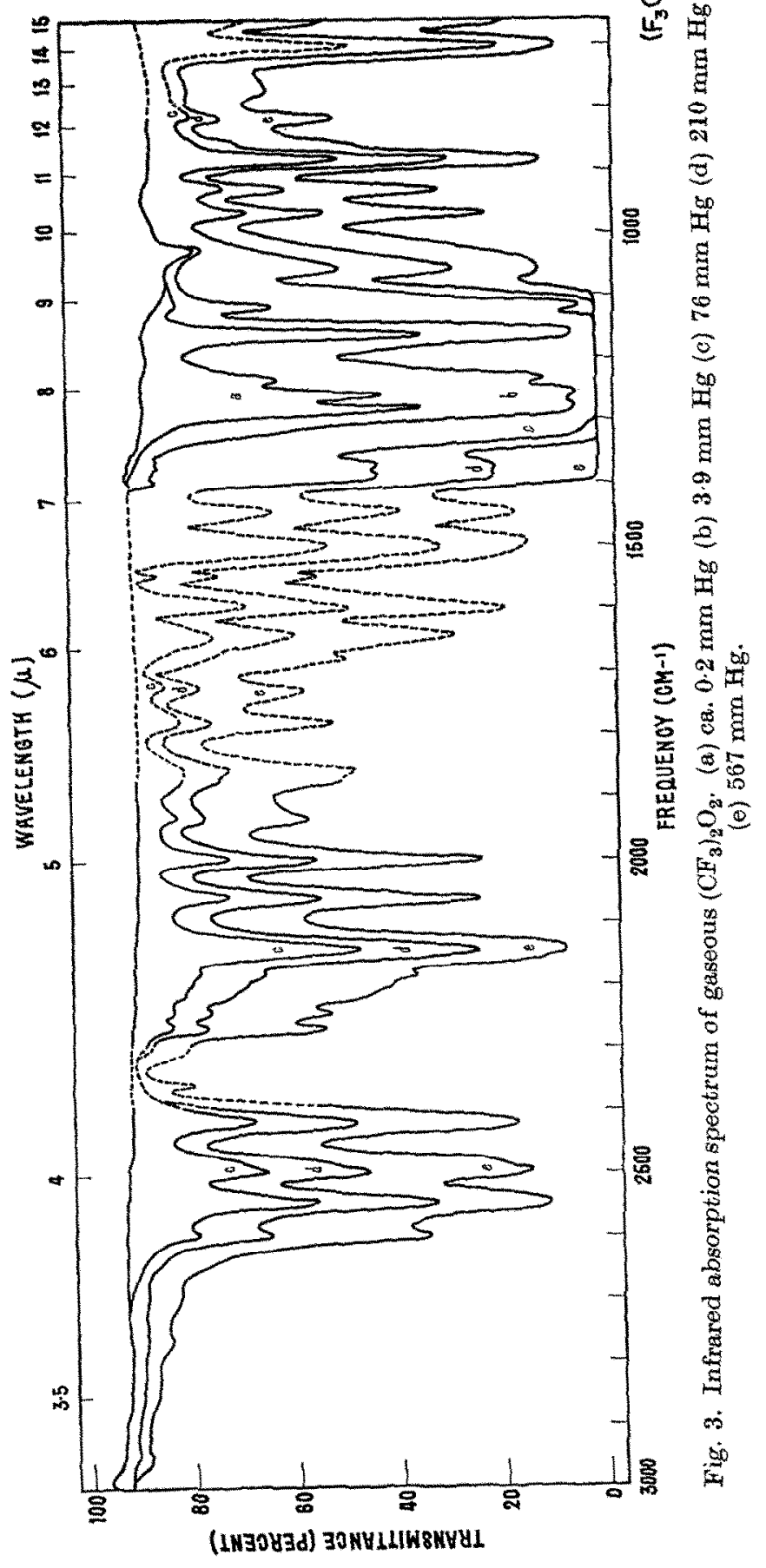




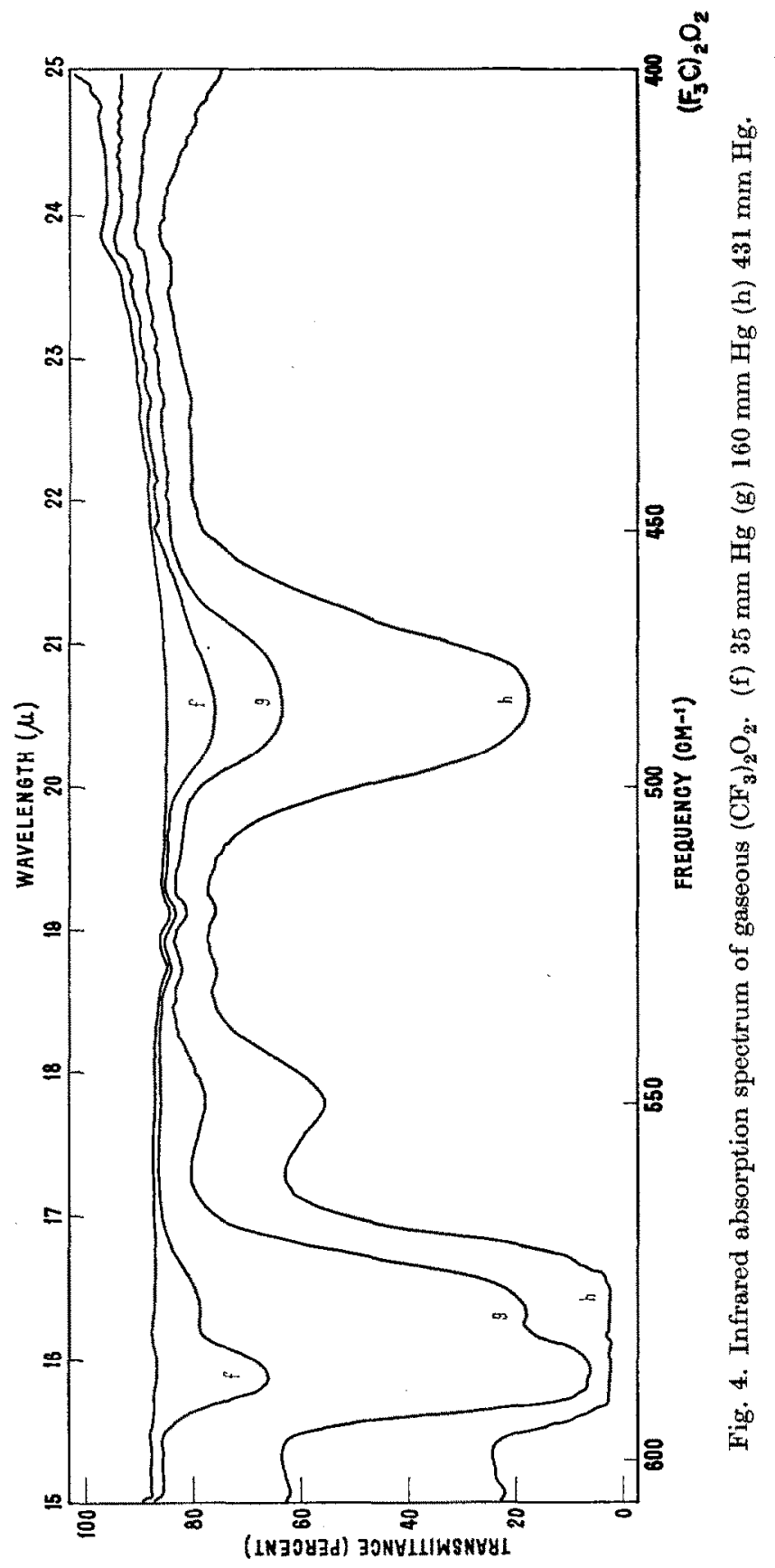


Table 1. Infrared spectrum of gaseous $(\mathrm{FCO})_{2} \mathrm{O}_{2}$

\begin{tabular}{|c|c|c|}
\hline Frequency $\left(\mathrm{cm}^{-1}\right)$ & Description & Interpretation \\
\hline \multicolumn{3}{|l|}{$582)$} \\
\hline 586 & s & $\mathrm{F}-\mathrm{C}-\mathrm{O}$ symmetrical deformation (bending) \\
\hline \multicolumn{3}{|r|}{ 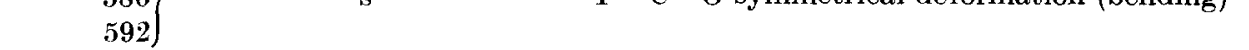 } \\
\hline 660 & $\mathbf{m}$ & $\mathrm{F}-\mathrm{C}-\mathrm{O}$ asymmetrical deformation (rocking) \\
\hline 749 & s & $\mathrm{O}=\mathrm{C}$ out-of-plane deformation \\
\hline 817 & $\mathbf{w}$ & fundamental? \\
\hline 912 & $\mathbf{m}$ & $\mathrm{O}-\mathrm{O}$ stretching \\
\hline 954 & s & $\mathrm{C}-\mathrm{O}$ stretching \\
\hline 1016 & $\mathrm{~m}$ & $\mathrm{C}-\mathrm{O}$ stretching \\
\hline $1085 \mathrm{sh}$ & $w$ & combination \\
\hline 1101 & w & combination \\
\hline 1178 & vvs & $C-F$ stretching \\
\hline 1221 & $\mathbf{s}$ & $\mathrm{C}-\mathrm{F}$ stretching \\
\hline 1283 & $w$ & combination \\
\hline 1319 & $\mathrm{~m}$ & $660 \times 2=1320$ \\
\hline $1345 \mathrm{sh}$ & vvw & combination \\
\hline 1371 & $\mathrm{w}$ & combination \\
\hline 1501 & $\mathbf{w}$ & $749 \times 2=1498$ \\
\hline ca. 1580 & $w$ & $660+912=1572$ \\
\hline 1610 & w & $660+954=1614$ \\
\hline ca. 1660 & vw & $749+912=1661$ \\
\hline ca. 1734 & w & $817 ?+912=1729$ \\
\hline \multirow[t]{2}{*}{ ca. 1763} & \multirow[t]{2}{*}{ vw } & $586+1178=1764$ \\
\hline & & $749+1016=1765$ \\
\hline $\begin{array}{l}1899 \\
1905\end{array}$ & vs & $\mathrm{C}=\mathrm{O}$ stretching \\
\hline 1934 & vs & $\mathrm{C}=\mathrm{O}$ stretching \\
\hline 2028 & m & $1016 \times 2=2032$ \\
\hline 2095 & w & $912+1178=2090$ \\
\hline 2134 & $w$ & $954+1178=2132$ \\
\hline 2177 & $\mathrm{~m}$ & $954+1221=2175$ \\
\hline 2239 & vw & $1016+1221=2237$ \\
\hline ca. 2351 & $\mathrm{w} ?$ & $1178 \times 2=2356$ \\
\hline 2401 & m & $1178+1221=2399$ \\
\hline 2452 & w & $749 \times 2+954=2452$ \\
\hline 2654 & vvw & $749 \pm 1902=2651$ \\
\hline 2818 & vw & $912+1902=2814$ \\
\hline 2855 & $\mathbf{w}$ & $954+1902-2856$ \\
\hline 2898 & $w$ & $954+1934=2888$ \\
\hline 2947 & vw & $1016+1934=2950$ \\
\hline 3046 & vvw & $912 \times 2+1221=3045$ \\
\hline $3079 \mathrm{sh}$ & vvw & $1178+1902=3080$ \\
\hline 3116 & vw & $1178+1934=3112$ \\
\hline & & $1221+1902=3123$ \\
\hline 3182 & vvw & $1221 \times 2+749=3191$ \\
\hline 3306 & vvw & $1178 \times 2+954=3310$ \\
\hline 3343 & vvw & $1221 \times 2+912=3353$ \\
\hline 3399 & vvw & $749 \times 2+1902=3400$ \\
\hline 3535 & vvw & $1178 \times 3=3534$ \\
\hline ca. 3712 & vvw & combination \\
\hline ca. 3800 & $\mathbf{m}$ & $1902 \times 2=3804$ \\
\hline ca. 3820 & m & $1902+1934=3836$ \\
\hline ca. 3868 & $\mathrm{vw}$ & $1934 \times 2=3868$ \\
\hline
\end{tabular}


Table 2. Infrared spectrum of gaseous $\left(\mathrm{F}_{3} \mathrm{C}\right)_{2} \mathrm{O}_{2}$

Frequency $\left(\mathrm{cm}^{-1}\right)$ Description Interpretation

\begin{tabular}{|c|c|c|}
\hline ca. 400 & ? & fundamental \\
\hline 480 & $\mathrm{~m}$ & $\mathrm{~F}_{3} \mathrm{C}$ asymmetric deformation \\
\hline 556 & $\mathbf{w}$ & $\mathrm{F}_{3} \mathrm{C}$ asymmetric deformation \\
\hline 606 & $\mathbf{s}$ & $\mathrm{F}_{3} \mathrm{C}$ asymmetric deformation \\
\hline 625 & $\mathbf{s}$ & $\mathrm{F}_{3} \mathrm{C}$ asymmetric deformation \\
\hline 673 & $\mathrm{~m}$ & $\mathrm{~F}_{3} \mathrm{C}$ symmetric deformation \\
\hline 715 & $\mathrm{~m}$ & $\mathrm{~F}_{3} \mathrm{C}$ symmetric deformation \\
\hline $\mathbf{7 7 5}$ & vw & $?$ \\
\hline 821 & $\mathbf{w}$ & $\mathrm{O}-\mathrm{O}$ stretching \\
\hline $865 \mathrm{sh}$ & vvw & ca. $400+480=$ ca. 880 \\
\hline 886 & $\mathrm{~m}$ & $\mathrm{C}-\mathrm{O}$ stretching \\
\hline 935 & $\mathbf{w}$ & combination? \\
\hline 974 & $\mathbf{w}$ & $\mathrm{C}-\mathrm{O}$ stretching \\
\hline 1062 & $\mathrm{~m}$ & ca. $400+673=$ ca. 1073 \\
\hline 1122 & $\mathbf{s}$ & $\mathrm{F}_{3} \mathrm{C}$ symmetric stretching \\
\hline 1167 & vvs & $\mathrm{F}_{3} \mathrm{C}$ symmetric stretching \\
\hline 1238 & vs & $\mathrm{F}_{3} \mathrm{C}$ asymmetric stretching \\
\hline 1265 & vvs & $\mathrm{F}_{3} \mathrm{C}$ asymmetric stretching \\
\hline 1285 & vvg & $\mathrm{F}_{3} \mathrm{C}$ asymmetric stretching \\
\hline ca. 1375 & $\mathbf{w}$ & $480+886=1366$ \\
\hline ca. 1391 & $\mathbf{w}$ & $673+715=1388$ \\
\hline ca. 1449 & $w$ & $625+821=1446$ \\
\hline ca. 1508 & $\mathbf{w}$ & $625+886=1511$ \\
\hline ca. 1599 & $\mathbf{w}$ & $715+886=1601$ \\
\hline ca. 1647 & $\mathbf{w}$ & $673+974=1647$ \\
\hline ca. 1731 & $\mathbf{v w}$ & $480+1265=1745$ \\
\hline ca. 1778 & vw & $480+1285=1765$ \\
\hline ca. 1855 & vw & $625+1238=1863$ \\
\hline 1930 & $\mathbf{w}$ & $956 \times 2=1912$ \\
\hline 1996 & $\mathbf{w}$ & $715+1285=2000$ \\
\hline 2058 & $\mathbf{w}$ & $821+1238=2059$ \\
\hline 2141 & m & $974+1167=2141$ \\
\hline 2181 & vvw & $886+1285-2171$ \\
\hline 2241 & vw & $1122 \times 2=2244$ \\
\hline 2263 & vw & $974+1285=2259$ \\
\hline ca. 2323 & $?$ & $1167 \times 2=2334$ \\
\hline ca. 2350 & $?$ & $1122+1238=2360$ \\
\hline 2415 & $\mathbf{w}$ & $1122+1285=2407$ \\
\hline 2493 & $\mathbf{w}$ & $1251 \times 2=2502$ \\
\hline 2540 & $\mathrm{~m}$ & $1251+1285=2536$ \\
\hline 2590 & vw & $673 \times 2+1251=2597$ \\
\hline
\end{tabular}

$\mathrm{v}$ : very, s: strong, $\mathrm{m}$; medium, w: weak, sh: shoulder. 
within the regions $1928-1750 \mathrm{~cm}^{-1}$ and $774-800 \mathrm{~cm}^{-1}$, which are the extreme frequencies observed in $\mathrm{F}_{2} \mathrm{CO}$ and organic carbonates for those vibrations. As may be seen in Table 1 the IR spectrum of BMFCP shows the predicted bands, some of them clearly split by interaction with the $\mathrm{O}=\mathrm{C}$ groups. The splitting found for the $\mathrm{C}=\mathrm{O}$ stretching frequency $\left(32 \mathrm{~cm}^{-1}\right)$ is close to the value expected for the acyl peroxides [10]. 'The $\mathrm{C}^{\mathrm{C}}-\mathrm{F}^{\mathrm{H}}$ stretching vibration shows a larger splitting $\left(43 \mathrm{~cm}^{-1}\right)$ which may be caused by a greater interaction. In the region of the $\mathrm{C}-\mathrm{O}$ stretching, the strong band located at $954 \mathrm{~cm}^{-1}$ occurs between other two bands of lower intensity. Although they are very similar, we have assigned that at $1016 \mathrm{~cm}^{-1}$ to the second $\mathrm{C}-\mathrm{O}$ stretching vibration because it is in the expected region. As for each pair of bands duc to the $\mathrm{C}=\mathrm{O}$ and $\mathrm{C}-\mathrm{F}$ vibrations, the higher the band frequency, the lower its intensity.

The $\mathrm{C}-\mathrm{O}$ stretching bands in BMFCP show therefore a separation of $62 \mathrm{~cm}^{-1}$ which is larger than the splitting observed for other stretching modes, possibly because the $\mathrm{C}-\mathrm{O}$ groups are immediate neighbours.

The medium band located at $912 \mathrm{~cm}^{-1}$ has been tentatively assigned to the $\mathrm{O}-\mathrm{O}$ stretching vibration because many organic peroxides, specially the acyl peroxides, absorb in the same region [11]. As SHEPPARD has pointed out [12], the low intensity of this band is probably due to the slight change produced in the dipole moment of the molecule by the relatively symmetrical $\mathrm{O}-\mathrm{O}$ vibration. This band is useful in explaining several combination bands.

On the above basis, the band found at $749 \mathrm{~cm}^{-1}$ could be assigned to an out-ofplane deformation of the $\mathrm{O}=\mathrm{C}$ group because it coincides with the low frequency branch of $v_{6}$ in $\mathrm{F}_{2} \mathrm{CO}$. The interpretation of the weak hand at $817 \mathrm{~cm}^{-1}$ becomes difficult because the information given by the IR spectrum is not enough to decide about its nature. Since it is close to the high-frequency branch (located at ca. 794 $\mathrm{cm}^{-1}$ ) of the out-of-plane deformation band of $\mathrm{F}_{2} \mathrm{CO}\left(v_{6}\right)$, it could be the second fundamental band related to the same deformation mode of the $\mathrm{O}-\mathrm{C}$ groups in the BMFCP molecule. This would imply a splitting of $68 \mathrm{~cm}^{-1}$ between the two out-ofplane vibration bands for the peroxide molecule. Moreover, if it is taken as a fundamental band, one can explain the weak band located at ca. $1734 \mathrm{~cm}^{-1}$. Nevertheless, we cannot exclude the possibility that it could be a combination band, which would involve a fundamental band located beyond $400 \mathrm{~cm}^{-1}$.

[10] L. J. Beflamy, The Infra-red Spectra of Complex Molecules, Chap. 8. Methuen, London (1956).

[11] L. J. Bellamy, Chap. 7.

[12] N. ShePPard, Discussions Faraday Soc. 9, 322 (1950). 
Between $749 \mathrm{~cm}^{-1}$ and the limit of the region covered by the $\mathrm{KBr}$ prism, there are only two bands at $660 \mathrm{~cm}^{-1}$ and $586 \mathrm{~cm}^{-1}$. These bands are near to the other two bands observed in the $\mathrm{F}_{2} \mathrm{CO}$ spectrum, which are due to different deformation modes. In connexion with the assignments of these bands it should be noted that recently OverEnd and Scherer [13] have questioned the interpretation given by NikLSEN et al. [9] to the $\mathrm{F}_{2} \mathrm{CO}$ bands found at 626 and $584 \mathrm{~cm}^{-1}$. Their calculations to determine the force constants according to Urey-Bradley, indicated that the band at 626 $\mathrm{cm}^{-1}$ should result from the $\mathrm{F}-\mathrm{C}-\mathrm{F}$ asymmetric deformation (rocking) and that at $584 \mathrm{~cm}^{-1}$ from the symmetric deformation (bending). Following those authors we can tentatively assign the band at $660 \mathrm{~cm}^{-1}$ in the BMFCP spectrum to the asymmetric deformation and the band at $586 \mathrm{~cm}^{-1}$ to the corresponding symmetric deformation. As in the case of the band of $\mathrm{F}_{2} \mathrm{CO}$ the latter shows three branches of nearly equal intensity. The remaining fundamental bands are expected below 400 $\mathrm{cm}^{-1}$, beyond the range of the recorded spectra. The weak bands which have no assignments in Table 1 could probably be explained as combinations involving these bands.

\section{(b) The BTFMP spectrum}

The BTFMP molecule has ten atoms. Therefore, if there is no degeneracy, it should give rise to a maximum of twenty-four fundamental bands.

Formally, the BTFMP molecule could be considered as consisting of two trifluoromethoxyl radicals bonded through the oxygen atoms. Consequently, it would be interesting for comparison to consider the spectra of molecules containing that radical. Trifluoromethyl hypofluorite $\left(\mathrm{F}_{3} \mathrm{COF}\right)$ is undoubtedly the best studied from that point of view [14].

Each one of the pentatomic groups $\left(\mathrm{F}_{3} \mathrm{CO}\right)$ in BTFMP should be associated to nine fundamental vibrations: three $\mathrm{C}-\mathrm{F}$ stretching vibrations (two asymmetrical and one symmetrical), three $\mathrm{F}_{3} \mathrm{C}$ deformation vibrations (two asymmetrical and one symmetrical), the $\mathrm{F}_{3} \mathrm{C}$ rocking and wagging and the $\mathrm{C}-\mathrm{O}$ stretching vibration. To these eighteen vibrations we have to add the $\mathrm{O}-\mathrm{O}$ stretching vibration, the $\mathrm{F}_{3} \mathrm{CO}$ torsion around the $\mathrm{O}-\mathrm{O}$ bond, the $\mathrm{F}_{3} \mathrm{C}$ torsions around the $\mathrm{C}-\mathrm{O}$ bonds and finally, the $\mathrm{CO}-\mathrm{O}$ angular deformations.

Fig. 3 and Table 2 show that in the region corresponding to the $\mathrm{C}-\mathrm{F}$ stretching vibrations the BTFMP spectrum has three very strong bands located at 1285, 1265 and $1167 \mathrm{~cm}^{-1}$ and two others of lower intensity, at 1238 and $1122 \mathrm{~cm}^{-1}$.

The fact that the band at $1238 \mathrm{~cm}^{-1}$ has an asymmetric contour suggests it could be formed by the approximate overlapping of two bands having nearly equal intensity. If this interpretation is correct, there would be six bands in this region of the spectrum forming two sets, one consisting of four and the other of two bands. Six are precisely the $\mathrm{F}_{3} \mathrm{C}$ stretching vibrations expected from the two $\mathrm{F}_{3} \mathrm{CO}$ groups in the BTFMP molecule in the case of interaction. Therefore, four of those bands should be related to the $\mathrm{F}_{3} \mathrm{C}$ asymmetric stretching and two to the symmetric stretching vibrations.

As the $\mathrm{F}_{3} \mathrm{COF}$ molecule has its $\mathrm{F}_{3} \mathrm{C}$ asymmetric stretching bands at higher

[13] J. Overend and J. R. Scherer, J. Chem. Phys. 32, 1296 (1960).

[14ך R. T. Lagemann, E. A. Jones and P. J. H. Woltz, J. Chem. Phys. 20, 1768 (1952). 
frequencies (1282 and $\left.1259 \mathrm{~cm}^{-1}\right)$ than its symmetric band $\left(1220 \mathrm{~cm}^{-1}\right)$, it is reasonable to assign the 1285,1265 and $1238 \mathrm{~cm}^{-1}$ bands of BTFMP to the $F_{3} C$ asymmetric modes and the 1167 and $1122 \mathrm{~cm}^{-1}$ bands to the symmetric ones. The band located at $886 \mathrm{~cm}^{-1}$ in BTFMP spectrum can be directly assigned to a $\mathrm{C}-\mathrm{O}$ stretching vibration because $\mathrm{F}_{3} \mathrm{COF}$ has this band at $880 \mathrm{~cm}^{-1}$.

The second $\mathrm{C} O$ vibration in BTFMP could be related to one of the bands located at 935 or $974 \mathrm{~cm}^{-1}$. Although they are nearly the same intensity, the latter has been selected as the fundamental of this type because it is useful to explain several combination bands. On the other hand, the band at $935 \mathrm{~cm}^{-1}$, which apparently does not enter in any combination, could be interpreted as a combination itself which eventually would include a fundamental band located in the region of the spectrum beyond $400 \mathrm{~cm}^{-1}$.

If the assumptions made here are correct, the bands related to the $\mathrm{C}-\mathrm{O}$ stretching vibrations are shifted towards lower frequencies and split more widely in BTFMP $\left(88 \mathrm{~cm}^{-1}\right)$ than in BMFCP $\left(62 \mathrm{~cm}^{-1}\right)$. Supporting this assignment it may be mentioned that other molecules containing the atomic group $\mathrm{F}_{3} \mathrm{CO}$, such as perfluoromethyl ether [15] and trifluoromethyl esters isolated from the reaction products of trifluoromethoxyl fluoride with sulphur trioxide [16], show strong bands between 920 and $980 \mathrm{~cm}^{-1}$ which, by exclusion, could be assigned to the $\mathrm{C}-\mathrm{O}$ stretching vibration. Comparing BTFMP with alkyl peroxides, its $\mathrm{O}-\mathrm{O}$ stretching band would be expected in the region between $8: 0$ and $880 \mathrm{~cm}^{-1}[11]$. The BTFMP spectrum shows only a weak band in the region located at $821 \mathrm{~cm}^{-1}$, which could be tentatively assigned to that vibration.

Between 715 and $480 \mathrm{~cm}^{-1}$ there are bands which could be related to the $\mathrm{F}_{3} \mathrm{C}$ deformation vibrations, by a comparison with the $F_{3} C O F$ spectrum. The latter substance shows three bands centered at 679,609 and $586 \mathrm{~cm}^{-1}$ which were assigned to the $F_{3} \mathrm{C}$ deformations. In BTFMP the six hands expected from the two trifluoromethyl groups would cover a wider region of the spectrum than in $\mathrm{F}_{3} \mathrm{COF}$, as it seems to occur with the bands originated by the $\mathrm{C}-\mathrm{F}$ stretching vibrations. The six bands found between the above mentioned limits and assigned to the $\mathrm{F}_{3} \mathrm{C}$ deformation vibrations could be further divided into two groups according to their symmetry as listed in Table 2 by direct comparison with the $F_{3} C O F$ spectrum.

Finally, there is a band located at ca. $400 \mathrm{~cm}^{-1}$ which is probably originated by one of the wagging or rocking vibrations, the rest of which are expected at still lower frequencies.

Acknouledgements-To Prof. Dr. H. J. Schumacher, Director of the Instituto Superior de Investigaciones, for his interest in this work.

Tu Mr. J. Olabe and Mr. E. VaretTi for the assistance in the preparation of BTFMP.

[15] D. G. WeIblen, Fluorine Chemistry (Edited by J. H. Srmons) Vol. II, p. 479. Academic Press, Now York (1954).

[16] W. P. VAN Meter and G. H. CADY, J. Am. Chem. Soc. 82, 6005 (1960). 